\title{
Haemodynamics and myocardial function after sotalol
}

\author{
I. Hutton, A. R. Lorimer, W. S. Hillis, D. McCall,
} J. M. Reid, and T. D. V. Lawrie

From the University Departments of Medical Cardiology and Anaesthetics, Royal Infirmary, Glasgow $C_{4}$, Scotland

The cardiovascular effects of the beta-adrenergic blocking agent, sotalol, have been assessed in a group of patients with heart disease. There was a significant reduction in heart rate and cardiac output, but stroke volume was unchanged. Systemic arterial and pulmonary artery pressures were not significantly altered. Indices of myocardial function ( $d p / d t \max$ and $V$ max) were also significantly reduced.

Though previous studies have reported that sotalol is devoid of myocardial depression associated with other beta-adrenergic blocking drugs, these results suggest that sotalol has both a negative chronotropic and a lesser negative inotropic action.

Beta-adrenergic blocking drugs are now widely used in clinical cardiology. In addition to beta-adrenergic blockade, however, undesirable effects such as myocardial depression may occur (Nakano and Kusakari, 1966; Blinks, 1967). Sotalol (M.J., I999) ${ }^{1}$ has been reported to be a beta-adrenergic blocking agent devoid of significant myocardial depression (Lish, Weikel, and Dungan, 1965; Levy and Richards, 1965). Though studies of sotalol in man have been reported (Brooks et al., 1970; Svedmyr, Malmberg, and Häggendal, 1970), little is known of the effect of this drug on myocardial contractility in patients with heart disease. The purpose of the present study was to assess the cardiovascular effects of sotalol with particular reference to myocardial contractility.

\section{Methods}

Twelve patients, aged 24 to 52 years, were studied in the fasting state during cardiac catheterization carried out for diagnostic purposes and assessment for cardiac surgery (Table I). Each patient gave permission for the use of sotalol. None of the patients was in cardiac failure at the time of the study. The effect of sotalol was investigated in 2 groups of 6 patients. The first group had haemodynamic measurements made before and after sotalol administration. Four of these patients were in sinus rhythm and 2 were in atrial fibrillation,

1 dl 4-(2-isopropylamino-1-hydroxyethyl) methane sulphonanilide hydrochloride.

Received 22 October 197 I. receiving digoxin therapy. The second group had studies of myocardial contractility performed. All of these patients were in sinus rhythm and none was receiving digoxin. In each group sotalol was administered intravenously in a dosage of 0.2 $\mathrm{mg} / \mathrm{kg}$ body weight.

The heart rate was obtained from a continuously recorded electrocardiogram. Pulmonary artery pressure was recorded using a Goodale-

TABLE I Clinical details of patients studied

\begin{tabular}{|c|c|c|c|c|}
\hline & $\begin{array}{l}\text { Age } \\
(y r)\end{array}$ & Diagnosis & $\begin{array}{l}\text { Disability } \\
\text { grade (New } \\
\text { York Heart } \\
\text { Association) }\end{array}$ & Cardiac rhythm \\
\hline \multicolumn{5}{|c|}{$\begin{array}{l}\text { Group I } \\
\text { Haemodynamic studies: }\end{array}$} \\
\hline Patient I & 40 & Mitral stenosis & II & Sinus \\
\hline 2 & 39 & Mitral stenosis & II & Atrial fibrillation \\
\hline 3 & 48 & Mitral stenosis & I & Sinus \\
\hline 4 & 41 & Mitral stenosis & III & Atrial fibrillation \\
\hline 5 & 42 & Mitral stenosis & II & Sinus \\
\hline 6 & 37 & $\begin{array}{l}\text { Mitral stenosis and } \\
\text { incompetence }\end{array}$ & II & Sinus \\
\hline \multicolumn{5}{|c|}{$\begin{array}{l}\text { Group II } \\
\text { Myocardial contractility } \\
\text { studies: }\end{array}$} \\
\hline Patient I & 28 & $\begin{array}{l}\text { Systolic murmur; no } \\
\text { cardiac lesion found }\end{array}$ & I & Sinus \\
\hline 2 & 24 & Mitral stenosis & II & Sinus \\
\hline 3 & 43 & Mitral stenosis & II & Sinus \\
\hline 4 & 52 & $\begin{array}{l}\text { Aortic stenosis (gra- } \\
\text { dient }<50 \text { mmHg) }\end{array}$ & $\mathrm{I}$ & Sinus \\
\hline 5 & 29 & Aortic incompetence & III & Sinus \\
\hline 6 & 37 & Mitral stenosis & II & Sinus \\
\hline
\end{tabular}


Lubin catheter ${ }^{1}$ (length $100 \mathrm{~cm}$, end and side aperture; internal diameter $1.42 \mathrm{~cm}$ ) inserted via an antecubital vein. Aortic pressure was recorded from a Gensini catheter ${ }^{1}$ (length $100 \mathrm{~cm}$, end and side aperture ; internal diameter $1.47 \mathrm{~mm}$ ) inserted into the femoral artery by the Seldinger technique and advanced into the ascending aorta. Pressures were measured by a capacitance transducer (Sanborn 267) and recorded on a multichannel photographic recorder at paper speeds of 10 and 25 $\mathrm{mm} / \mathrm{sec}$. The midthorax was taken as zero level with the patient supine. Mean pressures were obtained by electrical integration. Pressures were recorded for Io minutes before injection of sotalol and similarly for 20 minutes after injection. Cardiac output was estimated by the dye dilution technique using indocyanine green as the indicator. All cardiac output measurements were made in duplicate. Control measurements were made 5 minutes and $I$ minute before the injection of sotalol, and then 5, 10, and I5 minutes after the drug was administered. The appropriate dose of sotalol was injected over a 2-minute period and all measurements were timed from the mid point of injection. Derived measurements were:

Systemic vascular resistance

(dynes $\mathrm{sec} \mathrm{cm}^{-5}$ ) $=\frac{\text { Mean arterial pressure }(\mathrm{mmHg}) \times 80}{\text { Cardiac output }(1 . / \mathrm{min})}$

External cardiac work

(kg m/min)

Mean arterial pressure $(\mathrm{mmHg}) \times 13.6$ $=\frac{\times \text { cardiac output }(1 . / \mathrm{min}) \text {. }}{1000}$

Since changes in myocardial contractility may be rate related, it was necessary to maintain a constant heart rate before and after sotalol administration. This was done by atrial pacing using a NBIH bipolar pacing catheter ${ }^{1}$ introduced from an antecubital vein and positioned at the superior vena cava-right atrial junction. Throughout the study, the heart rate was maintained at ro beats a minute above its resting level. Left ventricular pressure was measured from a Gensini catheter introduced retrogradely through the aortic valve. The first derivative of left ventricular systolic pressure was measured electronically using a differentiating circuit (Sanborn 350-16 pressure derivative) and the maximum value recorded LV dp/dt max. Left ventricular end-diastolic pressure and the first derivative of left ventricular systolic pressure were recorded at a paper speed of $200 \mathrm{~mm} / \mathrm{sec}$ and the isovolumic segment of the left ventricular pressure tracing was used to calculate force velocity curves from the formula (Mason, 1969):

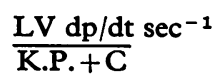

where $\mathrm{P}=\mathrm{LV}$ pressure $(\mathrm{mmHg})$

$\mathrm{LV} \mathrm{dp} / \mathrm{dt}=$ simultaneously measured rate of rise of $\mathrm{LV}$ pressure ( $\mathrm{mmHg}$ ).

$\mathrm{K}$ and $\mathrm{C}$ are constants $(K=40: \mathrm{C}=80$ ) (Parmley and Sonnenblick, I967).

1 United States Catheter and Instrument Corporation.
TABLE 2 Haemodynamic measurements before and after intravenous administration of sotalol

\begin{tabular}{|c|c|c|c|c|}
\hline Variables & Control & $5 \mathrm{~min}$ & $10 \min$ & $15 \min$ \\
\hline $\begin{array}{l}\text { Heart rate } \\
\text { Aortic systolic pressure }\end{array}$ & $83 \pm 6$ & $69 \pm 5 \ddagger$ & $70 \pm 5 \ddagger$ & $72 \pm 5 \ddagger$ \\
\hline $\begin{array}{l}(\mathrm{mmHg}) \\
\text { Aortic diastolic pressure }\end{array}$ & $130 \pm 9$ & $118 \pm 8 \dagger$ & $118 \pm 9 \dagger$ & $117 \pm 8+\bar{c}$ \\
\hline $\begin{array}{l}(\mathrm{mmHg}) \\
\text { Mean aortic pressure }\end{array}$ & $71 \pm 7$ & $68 \pm 7$ & $65 \pm 6$ & $68 \pm 6$ \\
\hline $\begin{array}{l}(\mathrm{mmHg}) \\
\text { Mean pulmonary artery }\end{array}$ & $89 \pm 4$ & $86 \pm 3$ & $87 \pm 3$ & $88 \pm 3$ \\
\hline pressure (mmHg) & $26 \pm 4$ & $27 \pm 4$ & $25 \pm 4$ & $25 \pm 4$ \\
\hline $\begin{array}{l}\text { Cardiac output (1./min) } \\
\text { Stroke volume (ml/beat) }\end{array}$ & $\begin{array}{l}5 \cdot 0 \pm 0 \cdot 3 \\
58 \pm 5\end{array}$ & $\begin{array}{l}3 \cdot 9 \pm 0 \cdot 2^{\star} \\
54 \pm 5\end{array}$ & $\begin{array}{l}4 \cdot 0 \pm 0 \cdot 4^{\star} \\
55 \pm 7\end{array}$ & $\begin{array}{l}4 \cdot 2 \pm 0 \cdot 2 \\
56 \pm 5\end{array}$ \\
\hline $\begin{array}{l}\text { Systemic vascular resistance } \\
\text { (dynes sec } \mathrm{cm}^{-5} \text { ) }\end{array}$ & $1466 \pm 130$ & $1834 \pm 128 t$ & $1748 \pm 149^{\star}$ & $1526 \pm 140$ \\
\hline $\begin{array}{l}\text { External cardiac work } \\
(\mathrm{kg} \mathrm{m} / \mathrm{min})\end{array}$ & $6 \cdot 2 \pm 0.2$ & $4 \cdot 6 \pm 0.5^{\star}$ & $4.7 \pm 0.3^{\star}$ & $5 \cdot 6 \pm 0 \cdot 4^{x}$ \\
\hline
\end{tabular}

$\pm=I S E$ of the mean.

$\star=\mathbf{P}<0.05$.

$t=P<0.01$.

$\ddagger=\mathrm{P}<0.001$.

An index of the contractile state of the myocardium was then obtained by extrapolation of the isovolumic segment of the force velocity curve back to zero pressure load - this value being described as $\mathrm{V}$ max.

\section{Results}

Haemodynamic results are shown in Table 2. Heart rate decreased significantly during the study from a control value of $83 \pm 6$ beats a minute to $69 \pm 5$ beats a minute. The cardiac output fell significantly from $5 \cdot 0 \pm 0.31 . / \mathrm{min}$ to $3.9 \pm 0.21 . / \mathrm{min}$ while the stroke volume was unchanged, suggesting that the decrease in cardiac output was rate related. The mean systemic arterial pressure fell slightly but not significantly and the mean pulmonary artery pressure was unaltered. There was a significant reduction in the derived variable of external cardiac work and a rise of approximately 25 per cent in systemic vascular resistance after sotalol administration. The changes in left ventricular $\mathrm{dp} / \mathrm{dt} \max$ and $\mathrm{V}$ max are shown in Table 3 and Fig. 1,2 , and 3. There was a significant reduction in both variables. There

TABLE 3 Myocardial function before and after intravenous administration of sotalol

\begin{tabular}{|c|c|c|c|}
\hline Variable & Control & $5 \min$ & $10 \mathrm{~min}$ \\
\hline $\begin{array}{l}\text { LV end-diastolic pressure (mmHg) } \\
\text { LV dp/dt max (mmHg/sec) } \\
\text { V max }\end{array}$ & $\begin{array}{l}6 \cdot 4 \pm 2 \cdot 1 \\
918 \pm 87 \\
0.44 \pm 0.04\end{array}$ & $\begin{array}{r}7 \cdot 2 \pm 1 \cdot 6 \\
690 \pm 57^{\star}\end{array}$ & $\begin{array}{c}7 \cdot 0 \pm 1 \cdot 8 \\
633 \pm 63^{\star} \\
0 \cdot 39 \pm 0 \cdot 03\end{array}$ \\
\hline
\end{tabular}




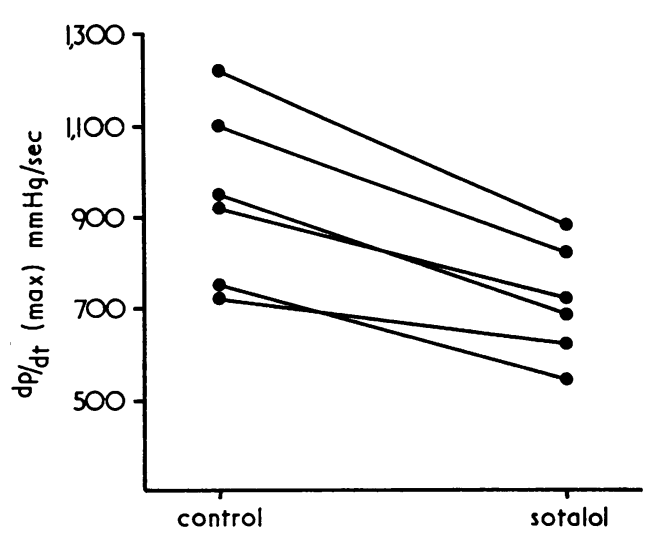

FIG. I The effect of intravenous administra'tion of sotalol on the $d p / d t$ (max).

was a small but non-significant increase in left ventricular end-diastolic pressure from $6 \cdot 4 \pm 2 \cdot 1$ to $7 \cdot 2 \pm 1 \cdot 6 \mathrm{mmHg}$.

\section{-Discussion}

Sotalol has been shown to be an effective betaadrenergic blocking agent in isolated cardiac muscle preparations (Lish et al., 1965) and in closed chest anaesthetized dogs (Puri and Bing, 1969). Levy and Richards (1965) and Lish et al. (1965) found no evidence of myon cardial depression after sotalol when studying an isolated cardiac muscle preparation. Blinks (1967), on the other hand, reported that sotalol did produce some depression of myocardial function in isolated guinea-pig atria though less than that found after propranolol. Brooks et al. (1970) studied the effects of sotalol in a group of patients with rheumatic heart disease of varying severity and including patients in congestive cardiac failure. They suggested that the haemodynamic effects of sota-

FIG. 2 The effect of intravenous administration of sotalol on the $V$ max.

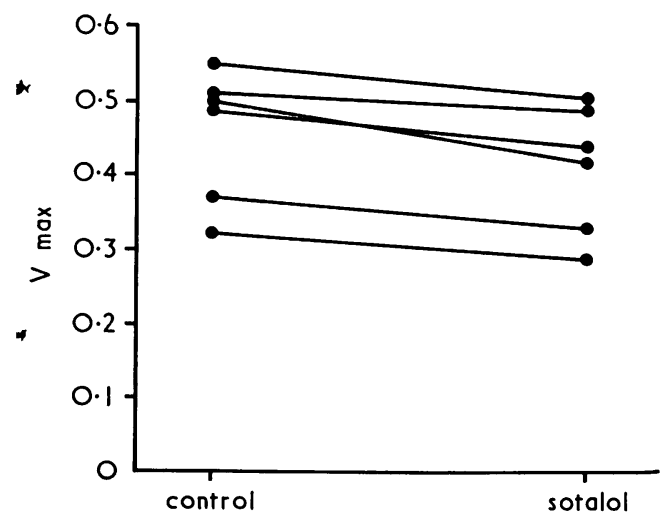

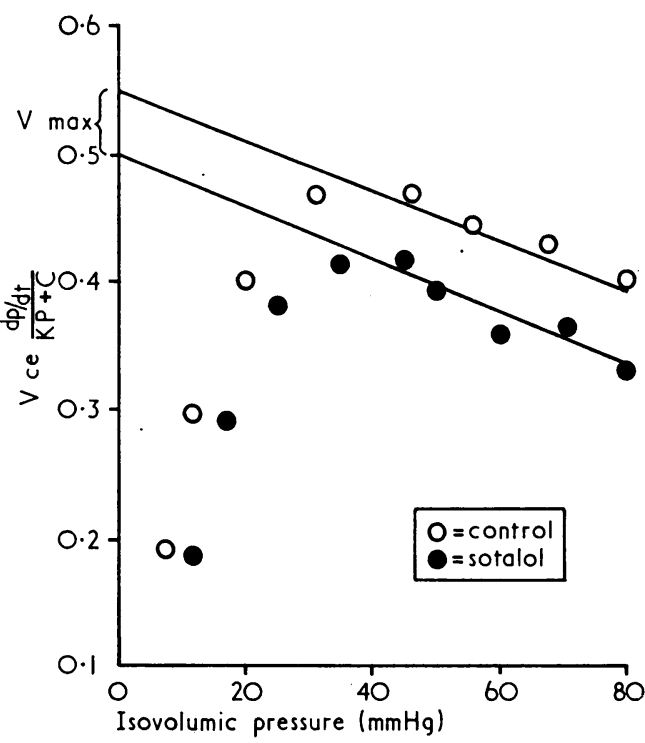

FIG. 3 Force velocity curves obtained from a patient before and after the intravenous administration of sotalol.

lol were due to a negative chronotropic action. They reported that sotalol did not have any negative inotropic action though this finding was mainly based on a study of anaesthetized, apparently healthy, dogs.

In the present study the intravenous administration of sotalol to a group of patients with valvular heart disease of varying severity (Table 2) but free from cardiac failure resulted in a significant fall in heart rate and cardiac output, while changes in stroke volume, mean systemic arterial pressure, and pulmonary artery pressure were slight and not significant. These results are consistent with a negative chronotropic action in keeping with a betaadrenergic blocking drug but differ from the haemodynamic changes found after propranolol (Sowton and Hamer, 1966), where a fall in stroke volume as well as cardiac output occurred. The increase in the calculated systemic vascular resistance found after sotalol is thought possibly to be secondary to reflex vasoconstriction in response to the decrease in cardiac output.

These data do not provide definitive evidence of the effect of sotalol on myocardial contractility. Furnival, Linden, and Snow (1970) suggested that the dp/dt max is a quantitative index of inotropic changes in the left ventricle and that though influenced by ventricular preload and after-load is useful in the assessment of directional changes of contractility in response to an inotropic drug or other 
intervention in an individual patient. Though there are a number of technical and theoretical limitations in the derivation of the velocity of shortening of the contractile element to zero load (V max), Falsetti et al. (I97I) assessed myocardial contractility by several methods and concluded that $\mathrm{V} \max$ was the most sensitive. In the present series, the left ventricular pressure measurements were obtained from a fluid-filled catheter system similar to that used by Hugenholtz et al. (1970) who compared a fluid-filled catheter system with a catheter tipped transducer and obtained comparable values for $\mathrm{dp} / \mathrm{dt}$ and $\mathrm{V}$ max. In the present study a constant heart rate was obtained by atrial pacing, thus allowing the effects of sotalol on myocardial contractility to be assessed independently of its negative chronotropic action. After injection of sotalol, the left ventricular end-diastolic pressure remained unchanged. There was, however, a reduction in myocardial contractility as shown by a significant decrease in left ventricular $\mathrm{dp} / \mathrm{dt} \max$ and a downward shift of the forcevelocity curve with a resultant fall in $\mathrm{V}$ max.

External cardiac work represents energy associated with myocardial shortening and is one of the factors determining myocardial oxygen consumption (Sonnenblick, Ross, and Braunwald, 1968). The significant reduction in external cardiac work in addition to the effect on the heart rate and the reduction in the velocity of myocardial contraction suggests that, in common with other beta-adrenergic blocking drugs, sotalol decreases myocardial oxygen consumption.

The above results are consistent with a betaadrenergic blocking drug which has a predominant rate-dependent effect but in addition has a modest depressant action on the myocardium. Further clinical evaluation of sotalol appears to be indicated.

\section{References}

Blinks, J. R. (1967). Evaluation of the cardiac effects of several beta-adrenergic blocking agents. Annals of the New York Academy of Sciences, 139, 673.
Brooks, H., Banas, J., Jr., Meister, S., Szucs, M., Jr., Dalen, J., and Dexter, L. (I970). Sotalol-induced beta-blockade in cardiac patients. Circulation, 42, 99.

Falsetti, H. L., Mates, R. E., Greene, D. G., and Bunnell, I. L. (197I). V max as an index of contractile state in man. Circulation, 43, 467.

Furnival, C. M., Linden, R. J., and Snow, H. M. (I970). Inotropic changes in the left ventricle: the effect of changes in heart rate, aortic pressure and end-diastolic pressure. Fournal of Physiology, 211, 359.

Hugenholtz, P. G., Ellison, R. C., Urschel, C. W., Mirsky, I., and Sonnenblick, E. H. (1970). Myocardial force-velocity relationships in clinical heart disease. Circulation, 41, 191.

Levy, J. V., and Richards, V. (1965). Inotropic and metabolic effects of three beta-adrenergic receptor blocking drugs on isolated rabbit left atria. Fournal of Pharmacology and Experimental Therapeutics, 150, 36r.

Lish, P. M., Weikel, J. H., and Dungan, K. W. (1965). Pharmacological and toxicological properties of two new beta-adrenergic receptor antagonists. Fournal of Pharmacology and Experimental Therapeutics, I49, $16 \mathrm{r}$.

Mason, D. T. (1969). Usefulness and limitations of the rate of rise of intraventricular pressure $(\mathrm{dp} / \mathrm{dt}$ ) in the evaluation of myocardial contractility in man. American fournal of Cardiology, 23, 516.

Nakano, J., and Kusakari, T. (1966). Effect of betaadrenergic blockade on the cardiovascular dynamics. American fournal of Physiology, 210, 833.

Parmley, W. W., and Sonnenblick, E. H. (1967). Series elasticity in heart muscle: its relation to contractile element velocity and proposed muscle models. Circulation Research, 20, 112.

Puri, P. S., and Bing, R. J. (1969). Effects on myocardial contractility, haemodynamics and cardiac metabolism of a new beta-adrenergic blocking drug, sotalol. Diseases of the Chest, 55, 235.

Sonnenblick, E. H., Ross, J., and Braunwald, E. (1968). Oxygen consumption of the heart. Newer concepts of its multifactorial determination. American fournal of Cardiology, 22, 328.

Sowton, E., and Hamer, J. (1966). Hemodynamic changes after beta-adrenergic blockade. American Fournal of Cardiology, 18, 317.

Svedmyr, N., Malmberg, R., and Häggendal, E. (1970). The haemodynamic effects of sotalol (M.J. 1999) and propranolol in man. Pharmacologia Clinica, 2, 82.

Requests for reprints to Dr. I. Hutton, University Department of Medical Cardiology, Royal Infirmary, Glasgow $\mathrm{C}_{4}$. 